\title{
PELATIHAN MODEL-MODEL PEMBELAJARAN ANAK USIA DINI DI POS PAUD KECAMATAN DELANGGU, KABUPATEN KLATEN
}

\author{
Ummi Hany Eprilia, Surtikanti, dan Aryati Prasetyarini \\ Jurusan PAUD - Fakultas Keguruan dan Ilmu Pendidikan \\ Universitas Muhammadiyah Surakarta
}

\begin{abstract}
The training for kindergarten teachers was conducted to equip them with knowlegde on the models of teaching to young learners. In general, the training involves the concept of teaching model, atractive model and its implementation, basic concept of teaching mathematics, reading and writing, and children cognitive development. After training, set of questionaire was distributed to see whether they master the knowledge given or not and to identify the teachers' needs to determine the next topic. Based on the questionaire, it was found that they need to learn classroom management, curriculum, and teaching methods. Since most of the participants (80\%) were housewives who did not have background knowledge on teaching young leaners, it was difficult enough to explain the knowledge. However, the participants confessed that they get knowlegde on how to teach young learners.
\end{abstract}

Kata kunci: pelatihan, model pembelajaran, Pos PAUD

\section{PENDAHULUAN}

\section{Analisis Situasi}

Melalui aktivitas bermain, berbagai pekerjaannya terwujud. Bermain adalah aktivitas yang dipilih sendiri oleh anak, karena menyenangkan, bukan karena akan memperoleh hadiah atau pujian. Hal ini berdasarkan asumsi bahwa anak adalah pembangun teori yang aktif (theory builder). Bermain adalah salah satu alat utama yang menjadi latihan untuk pertumbuhannya. Bermain adalah medium, di mana anak mencobakan diri, bukan saja dalam fantasinya tetapi juga benar nyata secara aktif. Bila anak bermain secara bebas, sesuai kemauan maupun sesuai kecepatannya sendiri, maka ia melatih kemampuannya untuk belajar (Agustin, 2005).

Model secara sederhana adalah "gambaran" yang dirancang untuk mewakili kenyataan. Model didefinisikan sebagai " $a$ replica of the fhenomena it attempts to explain" (Runyon, dalam Rakhmat, 1988:59). Jadi dalam kegiatan pembelajaran model dapat dimaknai sebagai suatu pola atau gambaran yang menjelaskan tentang berbagai bentuk, pandangan yang terkait dengan kegiatan pembelajaran.

Ciri khas pandangan Pestalozzi mengenai proses pendidikan Atrakfif yaitu melalui adanya pengajaran suara, bentuk dan bilangan. Semua bidang pengembangan yang 
diajarkan pada anak dikelompokkan dalam 3 kategori sebagai berikut.

1. Konsep suara mencakup bahan pengembangan bahasa, pengetahuan sejarah dan pengetahuan bumi.

2. Konsep bentuk mencakup pengetahuan bangun, menggambar dan menulis.

3. Konsep bilangan mencakup semua aspek yang berkaitan dengan berhitung.

Ketiga konsep di atas dapat melalui pengembangan AVM (Auditory Visual Memory). Melalui pengembangan AVM ini fungsi sel-sel syaraf akan berkembang dan selanjutnya akan dapat mengembangkan potensi-potensi lainnya seperti imajinasi, kreativitas, intelegensi, bakat, minat anak, misalnya dalam kelompok pengembangan auditori (bahasa), pengembangan perbendaharaan kosa kata anak dan kemampuan berkomunikasi harus mendapat perhatian intensif. Perbendaharaan kosakata akan menyentuh atau mempengaruhi dimensi potensi lainnya. Kemampuan anak berkomunikasi tergantung pada penguasaan kosakata anak.

Pelaksanaan dari pengembangan AVM dilaksanakan secara terpadu (intergrated). Kegiatan yang menggunakan metode percakapan dan bercerita, akan merupakan metode yang efektif dalam pengembangan AVM di TK.Sebagai contoh: memperkenalkan wama merah, bentuk bulat, rasa manis pada "Apel" merupakan salah satu model intergrated dalam pengembangan AVM.

a. Melalui gambar: anak diperkenalkan dengan pengertian "Apel".

b. Melalui kosakata: anak mengucapkan kata "apel".

c. Melalui bentuk: anak mengenal bentuk bulat.

d. Melalui bilangan :anak menghitung jumlahnya 1, 2, 3 dan seterusnya.

Model pendidikan ini, menitik beratkan pada pandangan seorang ahli pendidikan, Helen Parkhust yang lahir tahun 1807 di
Amerika. Pandangannya adalah kegiatan pengajaran harus disesuaikan dengan sifat dan keadaan individu yang mempunyai tempat dan irama perkembangan yang berbeda satu dengan yang lainnya. Setiap anak akan maju dan berkembang sesuai dengan kapasitas kemampuannya masingmasing. Walaupun demikian kegiatan pengajaran harus memberikan kemungkinan kepada murid untuk berinteraksi, bersosialisasi dan bekerja sama dengan murid lain dalam mengerjakan tugas tertentu secara mandiri. Pandangan ini mengisyaratkan bahwa Helen Parkhust tidak hanya mementingkan aspek individu, tapi juga aspek sosial.Untuk itu bentuk pengajaran ini merupakan keterpaduan antara bentuk klasikal dan bentuk individual. Sebagai gambaran pelaksanaan model ini, dapat diungkapkan sebagai berikut.

\section{a. Ruangan kelas}

Ruangan kelas dapat dimodifikasi menjadi kelas-kelas kecil, yang disebut ruangan vak atau sentra-sentra. Setiap ruangan vak atau sentra. terdiri atas satu bidang pengembangan. Ada sentra bahasa, sentra daya pikir, sentra daya cipta, sentra agama, sentra seni, sentra kemampuan motorik. Contohnya pada sentra bahasa terdapat bahan, alat-alat, serta sumber belajar seperti tape recorder, alat pendengar, kaset, alat peraga, gambar, dan sebagainya.

Pada sentra daya pikir berisi bahanbahan ajar seperti alat mengukur, manikmanik, lidi untuk menghitung, gambargambar, alat-alat geometris, alat-alat laboratorium atau majalah pengetahuan. Demikian pula pada sentra khusus seperti sentra balok, sentra air, sentra musik atau sentra bak pasir.

\section{b. Guru}

Setiap guru harus mencintai dan menguasai bidang pengembangan masingmasing. Guru harus memberi penjelasan 
secara umum kepada murid-murid yang mengunjungi sentranya sesuai dengan tema yang dipelajari. Memberi pengarahan, mengawasi dan mempematikan murid-murid ketika menggunakan alat-alat sesuai dengan materi yang dipelajarinya. .Selanjutnya menanyakan kesulitan yang dialami muridmurid dalam mengerjakan materi tersebut. Selain dari itu guru sentra harus menguasai perkembangan setiap murid dalam mengerjakan berbagai tugas s'ehingga dapat mengikuti tempo dan irama perkembangan setiap murid dalam menguasai bahan-bahan pengajaran atau tugas perkembangannya.

\section{c. Bahan dan Tugas}

Bahan pengajaran setiap sentra terdiri dari bahan minimal dan bahan tambahan. Bahan minimal yaitu bahan pengajaran yang berisi uraian perkembangan kemampuan minimal yang harus dikuasai setiap anak sesuai tingkat usianya. Bahan ini harus dikuasai anak dan merupakan target kemampuan minimal dalam mempeiajari setiap sentra tertentu.

Bahan setiap sentra hendaknya terintegrasi dengan sentra lainnya. Di bawah ini merupakan contoh adanya integrasi antar sentra dan bidang pengembangan.

\section{Tema : Tanaman}

Sentra bahasa : Dramatisasi "Fun Cooking”

Sentra music : bernyanyi menanam jagung

Sentra Aritmatika: belanja dan menghitung sayur-sayuran

Sentra air : memelihara dan merawat tanaman.

d. Murid dan Tugasnya

Setiap anak akan mendapat tugas dan penjelasan secara klasikal. Masing-masing anak dapat memilih sentra yang akan diikutinya. Anak bebas menentukan waktu dan menggunakan alat-alat untuk menyelesaikan tugasnya. Setiap anak tidak boleh mengerjakan tugas lain sebelum tugas yang dikerjakannya selesai. Untuk mengembangkan sosiobilitas, murid boleh mengerjakan tugas tertentu bersama-sama. Dengan cara ini murid akan mempunyai kesempatan bersosialisasi, bekerja sama, tolong menolong satu dengan lainnya. Murid yang dapat menyelesaikan suatu tugas atau sudah menguasai bahan minimal, ia dapat meminta tugas tambahan dengan memilih kegiatan lain yang digemarinya. Agar perbedaan setiap murid tidak terlalu jauh, guru dapat menetapkan bahan maksimal pada setiap pokok bahasan. Bila murid tidak dapat menyelesaikannya di sekolah, karena suatu hal, maka guru dapat memberi izin untuk menyelesaikannya di rumah.

\section{e. Penilaian Kemajuan Anak}

Menilai kemajuan murid digunakan tiga jenis kartu penilaian, yaitu kartu kemajuan individu, kartu rekapitulasi (mingguan, bulanan, catur wulan) dan kartu rekapitulasi laporan perkembangan setiap murid.

\section{Perumusan Masalah}

Metode kegiatan yang dilaksanakan adalah dengan empat metode, yaitu ceramah, workshop, tanya jawab, dan diskusi kelompok. Namun, metode yang ditempuh masingmasing pembicara berlainan, tergantung pada tema yang disajikan.

Berdasar analisis situasi di masyarakat, dapat diperoleh sebuah permasalahan yang dapat dirumuskan sebagai berikut: "Materi pembekalan apa yang dibutuhkan oleh guru/ pengurus/pengasuh Pos PAUD Kecamatan Delanggu, Kabupaten Klaten?"

Sesuai dengan permasalahan yang menjadi fokus pada kegiatan ini maka tujuan dan signifikansi dari kegiatan ini akan dipaparkan berikut ini. Kegiatan ini diharapkan dapat menjadi korporasi yang simbiosis 
mutualisme, sehingga kedua belah pihak dapat memperoleh manfaatnya. Masyarakat khusunya para guru/pengurus/pengasuh dapat memperoleh wawasan serta pengalaman tentang Model Pembelajaran AUD. Di samping

\section{Tinjauan Pustaka}

Surya (2002:11) mendefinisikan model pembelajaran sebagai berikut: "Pembelajaran adalah suatu proses yang dilakukan oleh individu untuk memperoleh suatu perubahan perilaku yang baru secara keseluruhan, sebagai hasil dari pengalaman individu itu sendiri dalam berinteraksi dengan lingkungannya". Pemahaman seorang guru terhadap pengertian pembelajaran akan mempengaruhi cara guru itu dalam mengajar. Berbagai definisi yang dikemukakan oleh para pakar, secara umum pembelajaran didefinisikan sebagai suatu proses perubahan yaitu perubahan dalam perilaku sebagai hasil interaksi antara dirinya dengan lingkungannya dalam memenuhi kebutuhan hidupnya.Beberapa prinsip yang menjadi landasan pengertian tersebut di atas ialah:

Pertama, pembelajaran sebagai usaha memperoleh perubahan perilaku. Prinsip ini mengandung makna bahwa ciri utama proses pembelajaran itu ialah adanya perubahan perilaku dalam diri individu. Artinya seseorang yang telah mengalami pembelajaran akan berubah perilakunya. Tetapi tidak semua perubahan perilaku itu adalah hasil pembelajaran. Perubahan perilaku sebagai hasil pembelajaran mempunyai ciri-ciri sebagai berikut ini (a) Perubahan yang disadari. Artinya individu yang melakukan proses pembelajaran menyadari bahwa pengetahuannya telah bertambah, keterampilannya telah bertambah dan mungkin saja ia telah lebih yakin terhadap kemampuan dirinya; (b) Perubahan yang bersifat kontinyu (berkesinambungan).
Artinya suatu perubahan yang telah terjadi sebagai hasil pembelajaran akan menyebabkan terjadinya perubahan yang lain. Misalnya, seorang anak yang telah belajar membaca, ia akan berubah perilakunya dari tidak mampu membaca menjadi dapat membaca; (c) Perubahan yang bersifat fungsional. Artinya perubahan yang telah diperoleh sebagai hasil pembelajaran memberikan manfaat bagi individu yang bersangkutan; (d) Perubahan yang bersifat positif. Artinya terjadi adanya pertambahan perubahan dalam diri individu. Perubahan yang diperoleh senantiasa bertambah sehingga berbeda dengan keadaan sebelumnya; (e) Perubahan yang bersifat aktif. Artinya perubahan itu tidak terjadi dengan sendirinya akan tetapi melalui aktivitas individu; (f) Perubahan yang bersifat permanen. Artinya perubahan yang terjadi sebagai hasil pembelajaran akan berada secara kekal dalam diri individu, setidak-tidaknya untuk masa tertentu; dan (g) Perubahan yang bertujuan dan terarah. Artinya perubahan itu terjadi karena ada sesuatu yang akan dicapai.

Kedua, hasil pembelajaran ditandai dengan perubahan perilaku secara keseluruhan. Prinsip ini mengandung arti bahwa perubahan perilaku sebagai hasil pembelajaran adalah meliputi semua aspek perilaku dan bukan hanya satu atau dua aspek saja. Perubahan perilaku itu meliputi aspekaspek perilaku kognitif, afektif dan juga motorik.

Ketiga, pembelajaran merupakan suatu proses. Prinsip ketiga ini mengandung makna bahwa pembelajaran itu merupakan suatu aktivitas yang berkesinambungan. Aktivitas itu terjadi adanya tahapan-tahapan aktivitas yang sistematis dan terarah. Jadi, pembelajaran bukan sebagai suatu benda atau keadaan yang statis, melainkan merupakan suatu rangkaian aktivitas-aktivitas yang dinamis dan saling berkaitan. Pembelajaran tidak dapat dilepaskan dengan interaksi individu dengan lingkungannya. 
Keempat, proses pembelajaran terjadi karena adanya sesuatu yang mendorong dan ada suatu tujuan yang akan dicapai. Prinsip ini mengandung arti bahwa aktivitas pembelajaran itu terjadi karena ada sesuatu yang mendorong dan sesuatu yang ingin dicapai. Hal yang mendorong adalah karena adanya kebutuhan yang harus dipuaskan, dan adanya tujuan yang ingin dicapai. Atas dasar prinsip itu, maka pembelajaran akan terjadi apabila individu merasakan adanya kebutuhan yang mendorong dan ada sesuatu yang perlu dicapai untuk memenuhi kebutuhannya. Dengan kata lain, pembelajaran merupakan aktivitas untuk memenuhi kebutuhan dan mencapai tujuan. Belajar tidak akan efektif tanpa adanya dorongan dan tujuan.

Kelima, pembelajaran merupakan bentuk pengalaman. Pengalaman pada dasarnya adalah kehidupan melalui situasi yang nyata dengan tujuan tertentu. Pembelajaran merupakan bentuk interaksi individu dengan lingkungannya, sehingga banyak memberikan pengalaman dari situasi nyata. Perubahan perilaku yang diperoleh dari pembelajaran, pada dasarnya merupakan pengalaman. Hal ini berarti bahwa selama individu dalam proses pembelajaran hendaknya tercipta suatu situasi kehidupan yang menyenangkan sehingga memberikan pengalaman yang berarti.

Memahami arti bermain bagi anak, maka dapat disimpulkan bahwa bermain merupakan suatu kebutuhan bagi anak dan tentunya pengabaian terhadap hal tersebut akan berdampak tidak baik bagi perkembangan anak selanjutnya. Penelitian yang dilakukan oleh Odom, Mc Connel dan Chandler (Semiawan, 2000) bahwa kegiatan bermain bagi anak $75 \%$ berkontribusi posistif terhadap perkembangan keterampilan sosialnya (social skills). Angka yang cukup tinggi tersebut setidaknya menggambarkan betapa penting kegiatan bermain bagi anak.
Belajar bermakna bagi anak sebenarnya berpijak pada prespektif apa yang dijadikan acuan. Tren yang sedang terjadi sekarang memandang bahwa paham kontruktivistik merupakan suatu aliran yang sangat mempengaruhi dunia pendidikan anak usia dini di negara-negara maju, khususnya di Eropa dan Amerika.

Aliran konstruktivistik berasumsi bahwa anak pada dasarnya memiliki kemampuan untuk membangun dan mengkreasi pengetahuan, pendekatan ini sangat menekankan pentingnya keterlibatan anak dalam proses belajar. Proses belajar dibuat secara natural, hangat dan menyenangkan melalui bermain dan berinteraksi secara harmonis dengan teman dan lingkungannya. Pada sisi yang lain, unsur variasi individual dan minat anak juga sangat diperhatikan sehingga motivasi belajar anak diharapkan muncul secara intrinsik.

Asumsi ini mengandung arti bahwa proses belajar yang bermakna terjadi kalau anak berbuat atas lingkungannya. Kesempatan anak untuk mengkreasi atau memanipulasi objek atau ide merupakan hal yang utama dalam proses belajar. Anak akan lebih banyak belajar dengan cara bermain berupa berbuat dan mencoba langsung daripada dengan cara mendengarkan orang dewasa yang memberikan penjelasan kepadanya.

Berpijak pada pandangan konstruktivistik, Bredekamp dan Rosegrant (Solahuddin 1997) menyimpulkan bahwa kegiatan belajar sambil bermain yang akan memberikan kebermaknaan bagi anak adalah apabila hal-hal sebagai berikut terlaksana:

a. Anak merasa aman secara psikologis serta kebutuhan-kebutuhan fisiknya terpenuhi ;

b. Anak mengkonstruksi pengetahuan;

c. Anak belajar melalui interaksi sosial dengan orang dewasa dan anak-anak lainnya; 
d. Minat dan kebutuhan anak untuk mengetahui terpenuhi; dan

e. Memperhatikan unsur variasi individual anak.

Semiawan (2002) menambahkan terkait dengan pentingnya belajar sambil bermain bagi anak. Menurut pandangannya, anak-anak yang kebutuhan bermainnya terpenuhi, akan makin tumbuh dengan memiliki keterampilan mental yang lebih tinggi. Menjelajahi dunianya lebih lanjut dan menjadi manusia yang memiliki kebebasan mental untuk tumbuh kembang sesuai dengan potensi yang dimilikinya Sehingga menjadi manusia yang bermartabat dan mandiri. Anak terlatih untuk terus menerus meningkatkan diri mencapai kemajuan.

Terdapat berbagai model pembelajaran anak usia dini yang didukung oleh aliranaliran, baik dalam kajian psikologi dan juga filsafat. Pertama adalah model pembelajaran behaviorisme. Menurut pandangan ini, belajar adalah suatu proses perubahan perilaku yang dapat diamati (observable) dan dapat diukur (meassurable). Behaviorisme menolak suatu referensi terhadap keadaan atau proses mental internal yang tidak dapat diamati dan diukur. Pendekatan terhadap belajar ini dicontohkan oleh kerja Thorndike \& Skinner (Masitoh, dkk, 2003) yang didasarkan atas suatu anggapan dari penelitian terhadap hewan dalam situasi belajar. Didasarkan pada eksperimen tersebut, kaum behavioris mengembangkan hipotesis bahwa proses belajar adalah penerapan hubungan stimulus-respon dengan control dari lingkungan dan control itu merupakan suatu hal yang potensial untuk penguatan. Menurut teori ini setiap orang merespon terhadap berbagai variabel yang terdapat dalam lingkungan. Kekuatankekuatan eksternal merangsang individu untuk bertindak dengan cara-cara tertentu mungkin positif, dan mungkin negatif. Karena teori ini didasari oleh asumsi bahwa pada prinsipnya individu itu dapat dibentuk oleh lingkungan, maka perlakuan terhadap individu melalui tugas, ganjaran, dan disiplin adalah sangat penting untuk mengembangkan kemampuan anak. Guru harus mempunyai peranan yang sangat dominan dalam mengendalikan proses pembelajaran mulai dari penentuan tujuan yang harus dicapai, pemilihan materi, sumber, dan metode pembelajaran maupun dalam proses mengevaluasi.

Model kedua adalah kognitivisme. Pandangan kognitif tentang belajar antara lain diilhami oleh hasil kerja Jean Piaget dan sejawatnya. Menurut Cohen (Masitoh, dkk, 2003)), model belajar ini secara umum ditandai sebagai tahapan teori yang menganjurkan bahwa proses berfikir anak dikembangkan melalui empat tahap yang berbeda. Menurut pendekatan ini proses berpikir bergantung pada suatu kemampuan untuk mencipta, memperoleh dan mengubah gambaran internal tentang segala sesuatu yang dialami di lingkungan. Pendekatan kognitif menekankan pada proses asimilasi dan akomodasi. Dalam hal ini anak menjadi problem solver dan pemroses informasi atau transformation processor. Aspek-aspek tersebut merupakan suatu rangkaian dalam proses belajar. Menurut pendekatan kognitif, belajar adalah sebagai perubahan perkembangan.

Model ketiga adalah konstruktivisme. Menurut pandangan ini anak adalah pembangun aktif pengetahuannya sendiri. Menurut De Vries (Masitoh, dkk, 2003)) anak harus membangun pengetahuan ketika mereka bermain. Anak membangun kecerdasannya, kemampuan untuk nalar, moral dan kepribadiannya. Pendekatan ini sangat menekankan pentingnya keterlibatan anak dalam proses belajar. Proses belajar hendaknya menyenangkan bagi anak, alami, melalui bermain, dan memberi kesempatan kepada anak untuk berinteraksi dengan 
lingkungannya. Menurut David H. Janassen (Masitoh, dkk, 2003)), "Constructivism proposes that learning environments should support multiple perspectives or interpretations of reality, knowledge, construction, and context, experience based activities". Artinya faham konstruktivisme menyatakan bahwa lingkungan belajar harus dapat mendukung berbagai perspektif atau interpretasi tentang kenyataan, pengetahuan, konstruksi dan konteks pengalaman yang didasarkan pada kegiatan.

Model selanjutnya adalah Pembelajaran Menurut Pendekatan High / Scope. Menurut pendekatan ini, anak memiliki potensi untuk mengembangkan pengetahuannya dan melibatkan interaksi yang bermakna antara anak dengan orang dewasa. Pengalaman sosial terjadi dalam konteks kehidupan nyata dimana anak memutuskan rencana dan inisiatifnya sendiri. Keterlibatan anak dalam proses belajar sangat penting sehingga mereka memperoleh kesempatan yang luas untuk berinteraksi dengan lingkungannya, dengan demikian lingkungan belajar harus dapat mendukung aktivitas belajar anak.

Model terakhir adalah progresivisme. Menurut Kohlberg dan Layen (Masitoh, dkk, 2003)) aliran ini berpandangan bahwa belajar adalah perubahan dalam pola berpikir melalui pengalaman memecahkan masalah. Ketika anak berinteraksi dengan lingkungan pengalaman nyata dan objek-objek nyata, anak akan mengalami masalah. Anak akan mencoba memecahkan sendiri masalah yang dihadapinya, dan ketika itu pula akan terjadi perubahan pola berpikir mereka.

\section{Tujuan dan Manfaat}

Pengabdian ini bertujuan untuk memberi pembekalan berupa pendidikan dan pelatihan tentang model pembelajaran bagi anak usia dini. Adapun manfaat yang diharapkan dengan terselenggaranya kegiatan ini pertama, para guru dan pengasuh memahami model pembelajaran untuk anak usia dini, meningkatkan pemahaman pengasuh/guru terhadap mitra kerja, meningkatkan kualitas emosi dan sosial dalam pembelajaran dan pengasuhan.

\section{HASIL DAN PEMBAHASAN}

Pengabdian ini dilaksanakan melalui ceramah, yaitu ceramah, workshop, tanya jawab, dan diskusi kelompok. Dari beberapa metode yang dilaksanakan, ceramah merupaka teknik yang dominan dalam kegitan ini. Ceramah membahasa tentang berbagai tema yang antara lain membaha tentang berbagai bentuk model pembelajaran. Keragaman pandangan tentang bentuk-bentuk pembelajaran anak usia dini. Pandangan dengan berbagai latar belakang filosofis banyak disebut dengan istilah model pembelajaran. Terdapat berbagai model pembelajaran anak usia dini yang didukung oleh aliran-aliran, baik dalam kajian psikologi dan juga filsafat. Diantara pandangan tersebut adalah sebagai berikut ini:

\section{Model Pembelajaran Menurut Pan- dangan Behaviorisme}

Menurut pandangan ini, belajar adalah suatu proses perubahan perilaku yang dapat diamati (observable) dan dapat diukur (meassurable). Behaviorisme menolak suatu referensi terhadap keadaan atau proses mental internal yang tidak dapat diamati dan diukur. Pendekatan terhadap belajar ini dicontohkan oleh kerja Thorndike \& Skinner (Masitoh, dkk, 2003) yang didasarkan atas suatu anggapan dari penelitian terhadap hewan dalam situasi belajar. Didasarkan pada eksperimen tersebut, kaum behavioris mengembangkan hipotesis bahwa proses belajar adalah penerapan hubungan stimulusrespon dengan control dari lingkungan dan control itu merupakan suatu hal yang potensial untuk penguatan. 
Menurut teori ini setiap orang merespon terhadap berbagai variabel yang terdapat dalam lingkungan. Kekuatankekuatan eksternal merangsang individu untuk bertindak dengan cara-cara tertentu mungkin positif, dan mungkin negatif. Karena teori ini didasari oleh asumsi bahwa pada prinsipnya individu itu dapat dibentuk oleh lingkungan, maka perlakuan terhadap individu melalui tugas, ganjaran, dan disiplin adalah sangat penting untuk mengembangkan kemampuan anak. Guru harus mempunyai peranan yang sangat dominan dalam mengendalikan proses pembelajaran mulai dari penentuan tujuan yang harus dicapai, pemilihan materi, sumber, dan metode pembelajaran maupun dalam proses mengevaluasi.

\section{Model Pembelajaran Menurut Pandangan Kognitivisme}

Pandangan kognitif tentang belajar antara lain diilhami oleh hasil kerja Jean Piaget dan sejawatnya. Menurut Cohen (Masitoh, dkk, 2003)), model belajar ini secara umum ditandai sebagai tahapan teori yang menganjurkan bahwa proses berfikir anak dikembangkan melalui empat tahap yang berbeda. Menurut pendekatan ini proses berpikir bergantung pada suatu kemampuan untuk mencipta, memperoleh dan mengubah gambaran internal tentang segala sesuatu yang dialami di lingkungan.

Pendekatan kognitif menekankan pada proses asimilasi dan akomodasi. Dalam hal ini anak menjadi problem solver dan pemroses informasi atau transformation processor. Aspek-aspek tersebut merupakan suatu rangkaian dalam proses belajar. Menurut pendekatan kognitif, belajar adalah sebagai perubahan perkembangan.

\section{Model Pembelajaran Menurut Pan- dangan Konstruksivisme}

Menurut pandangan ini anak adalah pembangun aktif pengetahuannya sendiri.
Menurut De Vries (Masitoh, dkk, 2003)) anak harus membangun pengetahuan ketika mereka bermain. Anak membangun kecerdasannya, kemampuan untuk nalar, moral dan kepribadiannya. Pendekatan ini sangat menekankan pentingnya keterlibatan anak dalam proses belajar. Proses belajar hendaknya menyenangkan bagi anak, alami, melalui bermain, dan memberi kesempatan kepada anak untuk berinteraksi dengan lingkungannya. Menurut David H. Janassen (Masitoh, dkk, 2003)), "Constructivism proposes that learning environments should support multiple perspectives or interpre-tations of reality, knowledge, construction, and context, experience based activities". Artinya faham konstruktivisme menyatakan bahwa lingkungan belajar harus dapat mendukung berbagai perspektif atau interpretasi tentang kenyataan, pengetahuan, konstruksi dan konteks pengalaman yang didasarkan pada kegiatan.

\section{Model Pembelajaran Menurut Pende- katan High / Scope \\ Menurut pendekatan ini, anak} memiliki potensi untuk mengembangkan pengetahuannya dan melibatkan interaksi yang bermakna antara anak dengan orang dewasa. Pengalaman sosial terjadi dalam konteks kehidupan nyata dimana anak memutuskan rencana dan inisiatifnya sendiri. Keterlibatan anak dalam proses belajar sangat penting sehingga mereka memperoleh kesempatan yang luas untuk berinteraksi dengan lingkungannya, dengan demikian lingkungan belajar harus dapat mendukung aktivitas belajar anak.

\section{Model Pembelajaran Menurut Pan- dangan Progresivisme}

Menurut Kohlberg dan Layen (Masitoh, dkk, 2003)) aliran ini berpandangan bahwa belajar adalah perubahan dalam pola berpikir melalui pengalaman memecahkan masalah. 
Ketika anak berinteraksi dengan lingkungan pengalaman nyata dan objek-objek nyata, anak akan mengalami masalah. Anak akan mencoba memecahkan sendiri masalah yang dihadapinya, dan ketika itu pula akan terjadi perubahan pola berpikir mereka.

Terdapat 2 contoh model pendidikan Atraktif, yaitu Pengajaran Suara, Bentuk dan Bilangan serta Sistem Pengajaran Sentra.

\section{Pengajaran Suara, Bentuk, dan Bilangan}

Konsep pengajaran suara, bentuk dan bilangan berawal dari konsep dasar yang dikemukakan oleh John Heindrich Pestalozzi. Walaupun Pestalozzi hidup pada abad 16, tapi pandangan dan konsep-konsepnya banyak yang menjadi kerangka dasar para pemikir pendidikan anak di abad sekarang. Salah satu karyanya berjudul "Die Methoden" yang mengupas tentang metodologi pembelajaran dalam beberapa bidang pelajaran. Salah satu pandangannya yang sangat relevan dalam pendidikan untuk PAUD atrakfif adalah konsep pembelajaran yang menekankan pada suara, behtuk dan bilangan. Konsep ini sangat dekat dengan pengembangan potensi anak pada dimensi auditori, visual dan memori yang tepat digunakan bagi perkembangan anak PAUD.

Pestalozzi mempunyai pandangan bahwa pendidikan bukanlah upaya menimbun pengetahuan pada anak didik. Pandangan ini menentang pengajaran yang "verbalists". Pandangan ini melandasi pemikirannya bahwa pendidikan pada hakikatnya usaha pertolongan (bantuan) pada anak agar anakmampu menolong dirinya sendiri yang dikenal dengan "Hilfe Zur Selfbsthilfe".Ditinjau konsepsi tujuan pendidikan, Pestolozzi sangat menekankan pengembangan aspek sosial pada anak sehingga anak dapat melakukan adaptasi dengan lingkungan sosialnya serta mampu menjadi anggota masyarakat yang berguna. Pendidikan sosial ini akan berkembang jika dimulai dari pendidikan keluarga yang baik.
Kegiatan pokok dalam pengabdian ini adalah pelaksanaan pelatihan/workshop untuk Pos PAUD Kecamatan Delanggu, Kabupaten Klaten. Kegiatan tersebut dilaksanakan sejak pagi hingga sore hari di Aula Serbaguna SMK Muhammadiyah Delanggu, Klaten. Sedangkan tema yang disajikan semuanya adalah tentang Model Pembelajaran secara umum, Model Atraktif dengan aplikasinya di pembelajaran Bahasa Inggris, Konsep dasar sebelum belajar Calistung (Baca, Tulis, dan Hitung) dan Kajian tentang Perkembangan Kognitif pada anak usia dini. Berikut adalah rincian tema dan metode yang disajikan.

Tabel 1.

Tema dan Metode Penyajian

\begin{tabular}{|c|l|l|l|}
\hline No & \multicolumn{1}{|c|}{ Nama } & \multicolumn{1}{|c|}{ Tema } & \multicolumn{1}{|c|}{$\begin{array}{l}\text { Metode } \\
\text { Penyampaian }\end{array}$} \\
\hline 1. & $\begin{array}{l}\text { Dra. Surtikanti, } \\
\text { M.Pd }\end{array}$ & $\begin{array}{l}\text { Model-Model Pembe- } \\
\text { lajaran Anak usia Dini }\end{array}$ & $\begin{array}{l}\text { Ceramah, Dis- } \\
\text { kusi dan Tanya } \\
\text { Jawab }\end{array}$ \\
\hline 2 & $\begin{array}{l}\text { Dra.Darsinah, } \\
\text { M.Si }\end{array}$ & $\begin{array}{l}\text { Perkembangan } \\
\text { Kognitif pada anak } \\
\text { Usia Dini }\end{array}$ & $\begin{array}{l}\text { Ceramah dan } \\
\text { Tanya Jawab }\end{array}$ \\
\hline 3 & Aryati P., M.Pd & $\begin{array}{l}\text { Model pembelajaran } \\
\text { Atraktif dengan } \\
\text { aplikasi pembelajaran } \\
\text { Bahasa Inggris }\end{array}$ & $\begin{array}{l}\text { Ceramah dan } \\
\text { Workshop }\end{array}$ \\
\hline 4 & $\begin{array}{l}\text { Ummi Hany } \\
\text { E,S.Psi,M.Pd }\end{array}$ & $\begin{array}{l}\text { Konsep-Konsep } \\
\text { Dasar pembelajaran } \\
\text { pada anak sebelum } \\
\text { belajar Calistung }\end{array}$ & $\begin{array}{l}\text { Ceramah dan } \\
\text { Workshop }\end{array}$ \\
\hline
\end{tabular}

Usai pelaksanaan kegiatan, diadakan survey tentang kebutuhan materi pengabdian yang paling dibutuhkan oleh peserta, yang akan di follow up pada pengabdian yang akan datang. Berdasar hasil observasi dan dialog dengan peserta diketahui bahwa pemahaman tentang pembelajaran, kurikulum dan metodemetode pengembangan, sangat dibutuhkan oleh peserta. Alasan utamanya karena latar belakang peserta yang menjadi guru/ pengasuh Pos PAUD di Delanggu tersebut hampir $80 \%$ adalah ibu rumah tangga yang belum pernah mendapatkan wawasan mengenai hal-hal diatas. Namun demikian, kegiatan pengabdian tersebut sangat membantu peserta membekali, menambah wawasan, meningkatkan percaya diri, dan 
senantiasa haus akan informasi mengenai kePAUD-an.

\section{SIMPULAN}

Materi pengabdian ini memberi banyak manfaat bagi peserta pelatihan. Pertama, peserta memiliki wawasan mengenai ke-PAUD-an, memiliki peningkatan kemampuan khususnya dalam model-model, mendapatkan pengetahuan baru tentang strategi yang dapat diterapkan ketika melakukan pembelajran di Pos PAUD. Namun, survey membuktikan bahwa materi yang dibutuhkan masih sangat kurang. Sehingga, dapat disimpulkan bahwa program ini memberi manfaat dan semangat yang banyak bagi masyarakat yang mengembangkan lembaga-lembaga PAUD. Tetapi, untuk kegiatan selanjutnya, dibutuhkan pengabdian masyarakat yang kontinue.

\section{DAFTAR PUSTAKA}

Agustin, M. 200). "Bermain bagi Anak Usia Dini: Permasalahan dan Penangannya". Jurnal Edukid. Vol 1. No 1 Juni 2005.

Depdiknas. 2000. Diklat calon instruktur guruTK atraktif, Pengembangan Model Pendidikan untuk TK Atraktif. Depdiknas, Dirjen Dikdasmen,PPPG Keguruan Jakarta, 2000.

Hapidin. 1999. Model-model Pendidikan untuk Anak Usia Dini. Jakarta: Ghiyats Alfiani Press.

Masitoh Dkk. 2003. Pendekatan Belajar Aktif di Taman Kanak-kanak. Depdiknas. Dikti. Proyek Peningkatan Pendidikan Tenaga Kependidikan.

Solehuddin, M. 1997. Konsep Dasar Pendidikan Prasekolah. Departemen Pendidikan dan Kebudayaan, Fakultas Ilmu Pendidikan, Institut Keguruan dan Ilmu Pendidikan; Bandung.

Surya, M. 2002. Psikologi Pembelajaran dan Pengajaran. Bandung: Yayasan Bhakti Winaya. Moeslichatoen R. 1999. Metode Pengajaran di Taman Kanak-Kanak. Depdikbud, Dirjen Dikti, Proyek Pendidikan Tenaga Akademik IKIP Malang. 